\title{
SOME CASES OF INTEGRATED SOCIAL SERVICES IN POLAND
}

\author{
Mirosław Grewiński \\ Joanna Lizut \\ Janusz Korczak Pedagogical University in Warsaw, Poland
}

\begin{abstract}
In Poland, public operations refer to the European debate on social policy and public policies, which focus on the development of social services and proper public management. An integrated approach to social services is the answer to the need for changes in the attitude to social problems, which require an extensive activity in the public field and the involvement of many organizations and institutions that create networks. This paper presents current experiences in integrating social services in Poland. Mostly, they have a local and testing character, but they are the "starting point" for the reorganization of the social assistance system. The integrated approach emphasizes the need of reorientation in perception of beneficiaries of social assistance, stimulating their activity and targeted public policies so that they take into consideration different lifestyles and needs. The reorganization and management of social policy system should lead to better social service delivery.
\end{abstract}

Keywords: social work, social assistance, social services, integrated approach to social services, social policy.

\section{Introduction}

It is a commonly shared idea that social innovation is the creation of social value by solving social problems (Mulgan, 2013). Accordingly, social innovation can be deemed to be the production of new solutions to social problems in a more effective, efficient, and sustainable way.

Analysing the consequences of the current economic crisis and its impact on daily life, one can find an idea that social innovation can constitute an effective strategy to counter-balance the retrenchment of public social provision (Palley, 2012).

There is a growing body of literature addressing social innovation of social services, closely related to social entrepreneurship and social enterprise (Lettice \& Parekh, 2010). However, the literature does not offer a consensus on the different approaches and solutions at a global level (MacLean, Harvey, \& Gordon, 2013).

Our opinion is that social problems should be understood in the context of the enormous societal change that is involving the contemporary society. 
Information and communication processes play a central role in our society. Computers are affecting human life in a great deal in that they are essential in all life dimensions. An increasing number of actions are made or run by computers and massive amount of multimedia materials circulate through the Internet. In a relatively short period of time, information and communication technology (ICT) has spread worldwide from defence, space and large industry applications, to business, hospitals, education and entertainment. New technologies have thoroughly penetrated into the everyday life, since they not only affect science and business, but also leisure and interpersonal relationships. Accordingly, new social phenomena are affecting our postmodern society: mass urbanisation, social exclusion, high rates of unemployment, environmental challenges, and so on. These challenges cross many boundaries: political, economic, technological and ecological (Bawa \& Munck, 2012), and solving those challenges requires designing innovative solutions, mobilising resources collectively and sharing ideas. As emphasised by Howaldt and Schwarz (2010, $5)$ : "[...] problems have in part changed radically and intensified in conjunction with the drastic acceleration of change in the economy, society and culture, and awareness has clearly grown regarding the limited potential that technological innovations and established management and problem-solving routines have to resolve issues".

This paper aims at illustrating some innovative social services provided in Poland. Our analysis focuses on the state of integration of social services, showing the advantages of an integrated approach.

The research method was designed to support an exploratory analysis based on direct observation and interviews with key persons involved in four different social services. Official documents, including website contents, have been examined and services' managers have been interviewed using a semi-structured questionnaire.

\section{Social innovative services in Poland}

In Poland, scientific and practitioners' debates on the role and importance of social services in social policy are relatively new, since for many years, in this country, the traditional approach to social policy dominated both in the social security system and the redistribution of public finances for social purposes. Social services have rarely been analysed as a separate category of social policy. It was a result from the practice of current social policy in Poland where social services were underdeveloped and in the shadow of financial and in-kind benefits. The change in the social policy theory was brought by a large EU project financed by the European Social Fund and conducted by Janusz Korczak Pedagogical University in Warsaw. In the framework of the above 
mentioned project named „Socially Responsible University” in the years 20092012 under the name „Socially Responsible University”, there was done a translation of the canon of European books from 4 languages, which brought the new perception of social policy in the context of its economization and marketization and new paradigms: active, multi-sector and investment social policy. Additionally, this project prepared several national experts and books on the diagnosis and evaluation of social services in four areas of social policy: social security, mainly in the health system and social assistance, social economy and corporate social responsibility, social work and environmental and employment policies and the labour market. This project, which evidently was pioneering in the context of dissemination of the service-oriented approach in social policy ended with a large international conference in 2011. Without any doubt it initiated, especially among the younger generation of scholars, an interest in the social service approach in social policy. You can notice it today by looking at the title of published papers, where social services are the main axis of analysis (Grewiński \& Rymsza, 2011).

Besides the increasing interest in social services as a conceptual category of social policy, increasing attention also focuses on specific issues, including the problems of integrating social services in order to improve the quality and individualization of benefits and in order to promote the efficiency and effectiveness of welfare interventions. The integration of services has been discussed in Poland since 2007, when the Ministry of Labour and Social Policy organized the first conference on this topic which focused on dissemination of a well-known report of a British author Brian Munday on integrated social services (Munday, 2007).

The cited report pointed out that the term "integrated social services" usually includes a "range of approaches or methods for achieving greater coordination and effectiveness between different services to achieve improved outcomes for service users" (Munday, 2007). However, as the authors point out, forms of integration can be very different: such as coordination of services, cooperation, partnership, structural integration. Many times these terms are used as synonyms. A similar approach is presented in the report "Integrated social services in Europe" prepared by the European Social Network; instead of focusing on definitional aspects, the publication exposes the main objective of creating an integrated services package to help people achieve lasting, positive social goals throughout their lives. The report refers to the provisions of the Social Investment Package, an indication of the European Commission to priorities in public policy for social investment principles and modernization of the welfare state.

Thus, it ought to be emphasized that in Poland discourse on social services refers to the European debate on social policy and the wider public policies. In 
this case, the development of social services is seen as a chance for more efficient and more effective provision of assistance (Grosse, 2008). It especially concerns the context and the message contained in the Green and White Book on Services of General Interest, which was developed by the institutions of the European Union a decade ago. Although, as we wrote above, in the academic scholarly discussion and among social activists, issues concerning social services are present for several years, however, the current integration of services in Poland is an experimental (innovative) practice rather than a systemic one (Grewiński \& Lizut, 2012).

Academicians and social activists, especially from the third sector, recognize a need that contemporary social problems require an extensive response in the public sphere and the involvement of many actors and institutions that create networks. There is a need for reorientation of the approach towards the recipients of the assistance and directing public policies that take into account different lifestyles and needs of beneficiaries and its administration and management would foster the development of the integrated social service system. In Poland, we have unfortunately seen far-reaching disagreement between the functioning of public policies, research proposals and social demands relating to these issues. The lack of a platform for cooperation causes a situation when the present system of support is divided into many smaller systems (relating to particular problems or issues: health, labour market, social assistance). There is a lack of programming, management and coordination of services at local and regional level (Grewiński \& Lizut, 2012), as seen from the perspective of the customer. There is also a lack is a long-term approach to social issues, recognition of the importance of continuity and coherence in public policies. We can also observe low engagement of policy makers who see social policy in terms of spending, and not from the perspective of social investment (Kościołek, 2012).

The available studies and expert opinions suggest that the current social policy is not only ineffective, but above all it does not bring positive outcomes. Most customers use cash benefits support; however, the amounts do not have a significant impact on improving the living conditions of recipients. According to data from the Central Statistical Office, households benefiting from external assistance (other than the traditional channels of support), most often use financial assistance ( $86 \%$ of all benefiting from external aid), more rarely inkind support $(51 \%)$ and the least popular is the form of services - $9 \%$ of those clients who are benefiting from external aid.

Services are provided simultaneously in several systems (for instance: services for the unemployed are provided within the social welfare system and the system of labour market policies). Care services are provided in the health care system and social care system and additionally may be supplemented by 
monetary benefits derived from the social security system (care allowance) or social care (care allowance) (Mitek, 2013). The main provider of services is the public sector, supplemented by Non-Governmental Organizazions (NGOs) and commercial firms. Many services are highly institutionalized (especially welfare and health), and their availability, quality and price are varied, mainly depending on the place of residence of the customer (Radlińska, 2008).

Within the social welfare system and the labour market, despite considerable investment in these issues, there is a lack of activation solutions, which can fundamentally and permanently change the customer situation. Additionally, organizational and administrative difficulties and deficits of system and legal solutions, which should work towards cooperation of different providers, in reality cause a lack of policy coherence and integration: both horizontally and vertically.

Currently one of the most important postulates towards the reforms of public policies is: focus on social services in support systems (social welfare, labour market and health), cross-sector partnership, the cooperation of institutions and organizations as well as the horizontal and vertical integration of services of different systems. Partnerships should contribute to co-ordination of services and benefits. Thus, co-operation is intended to facilitate access for beneficiaries to services and increase the complexity of the offer and cost effectiveness (Grewiński, Karwacki, 2010). Integration should provide individualization and customization of service packages provided to customers.

\section{Selected cases of social service integration in Poland}

In this part of article we present examples of the integration of social services in Poland. During the review and description of integrated services we wanted to verify whether they are implemented in a particular model (structural integration, sustainable partnerships, inter-institutional cooperation, multidisciplinary teams), and which experiences are worth for reproduction.

\section{Social Care and Culture Centre in Słupno}

First of the case studies provides the overview of changes which took place over the last decade in a small, rural village near Plock, located in the north of Mazovia Region- in Słupno. Thanks to the commitment of an extremely active local leader - director of the Social Welfare Centre - Joanna Augustowska - there was observed a spectacular and innovative for Polish conditions experiment involving the integration of various social services and social activities in the local environment that linked various instruments of intervention which are usually scattered across different systems of social policy. Within the framework 
of the Municipal Social Care Centre, which also operated under the name of Social Care and Culture Centre there was a success in integration in the same place of various social services which in Poland usually are provided separately. One-stop integration consisted of variety of services offered including: social assistance, care services, nursing, specialized services related to community social work, reintegration and mobilization of people at risk of social exclusion offered within the system of social economy and activation policy, social work and community social work, educational services for adults and cultural services as part of the process of active integration and organization of local communities (community organizing). In addition, Social Care Centre in Słupno was responsible for distribution of financial benefits and the implementation of family support. Within the Social Care Centre there was created not only a community centre but also the club of social integration, social cooperatives and occupational-therapy workshop and Theatre Group „A było tak.” The centre used very well known in Poland method of community social work which was developed by "CAL Association". This method focuses on bottom-top stimulation of citizens to be active and social inclusion in the spirit of empowerment. Whole local community started to undergo a change in the process of social integration through participation in numerous educational, cultural and integration events. Except development of personalized social services and cultural events, the centre implemented several innovative projects funded by the European Union. The achievements of the Centre were noticed quickly by the Ministry of Labour and Social Policy, Mazovian Centre for Social Policy and other institutions that started to award and give distinctions for being the best and most innovative Social Care Centre in Poland. Several study visits of various delegations of social workers from across Poland and abroad started to observe the case study on how this integrated model of services and social services works, which in Poland is not common. The centre also received the attention of the media and academia, which described an example of Stupno as the most promising experiment in social policy institution in Poland. Unfortunately, the local elections in 2014 after 10 years of very dynamic development of the Centre in Słupno brought a slowdown in new initiatives. The new mayor and the new government did not share the willingness to go further towards innovation and integration of services. This case study shows also how crucial it is to have a vision and as well provision of adequate leadership for social decision-making processes at the local level, which will not harm the development of such promising experiments and initiatives. 


\section{Community Centre Paca 40 - Warsaw}

Another example of integration of services comes from the Polish capital Warsaw. Municipal Office of Capital City Warsaw together with CAL Association finances and conducts for several years in the framework of publicsocial partnership and interesting initiative for the dwellers of Praga district. This community centre is focused on the integration of a variety of activities, educational and cultural services for various social groups - children and young people, women, the disabled and seniors, as well as all other residents of the district. In the framework of the Centre Paca 40 (CP40) everyone can find something interesting for themselves and their relatives. The recipients of the $\mathrm{CP}$ 40 services are both socially marginalized people and regular residents who are willing to join various initiatives. CP 40 offers various activities: sports and recreational, health education, educational (open lectures, training, courses), integration, cultural (theatre, cinema, opera), but also creates the possibility of implementing informal neighbourhood services. Within the centre the Bank of Neighbourhood Services was created which focus on matching of neighbours who exchange different products, services and things without cash (barter exchange). Beneficiaries of CP40 can also receive psychological and legal support there. Also coaching services are provided on the need. There is a Civic Advice Office and Integration Group eFKropka for people with mental and emotional problems. Visitors can also use other facilities such as: computer labs, a kitchen, different professional workshops and occupational therapy. On the site there are organized foreign language courses, computer learning, it is possible to practice yoga and tai chi. Additionally, it is possible to take part in handicraft workshops, poetry meetings or take part in table tennis or dance classes.

Centre Paca 40 is a good practice of integrating a variety of social, educational and cultural activities in one place and efficient coordination of them according to the needs of the participants - residents of the district.

The centre is managed by an experienced non-governmental organization, which is famous not only for educating in Poland, but also for the certification and validation process to stimulate local communities and their active integration in the services and community work, which require special attention. The effectiveness of the Centre is observed not only by the officials of the City of Warsaw to perhaps develop the concept of integrated services in other districts of Warsaw, but also by the mayors of other municipalities who treat CP40 as a signpost for their own social solutions. However, currently, the idea of establishing a similar centre is discussed by the authorities in one of the richest municipalities near Warsaw - Konstancin Jeziorna. 


\section{Integrated services for young people - TU PRAGA WAW PL - a local support system implemented under the program 'Family'}

In Warsaw Another interesting project in Warsaw was the integration of services project „TU PRAGA WAW PL”, which was based on the model of the Local Support System submitted as part of the „Family” program for 2010-2020 (Priority II, Providing assistance to families at risk of social exclusion, Objective 1 - the provision of an integrated range of services within local support system (www.warszawarodzinna.um.warszawa.pl). The main objective of the project was equalisation of educational and social opportunities to children aged 7- 18 living in disadvantaged district of Warsaw - Praga North, which is a place with the highest intensity of social problems Warsaw.

According to the report entitled: 'Teens at risk of social exclusion - their dreams, attitudes and behaviour and the environment in which they grow up,' $15 \%$ of the population of this area received various kinds of benefits and social security benefits (date based on the Centre for Social Welfare). In the total number of 3500 children living in the old part of Praga North, 1700 of them come from families affected by, various pathologies. What is more, about $30 \%$ of those children grow up in single-parent families without any regular sources of income, surviving crises. All of that contributes to the formation of marginalization and social exclusion. A high percentage of the population has low professional qualifications (58\% of the unemployed are people without secondary education, professional experience and qualifications).

The project has resulted in closer cooperation between non-governmental organizations and public institutions with schools and, as a result, to improve the educational outcomes of children and youth. To develop a comprehensive range of services for this group of customers, a consortium of civil society organizations has been appointed - Alternative Club (Caritas of the Diocese Warsaw-Praga), Group of the Association of Education and Social Association for Change, the Association of Heart for Children and the Society of Friends of Children and supporting institutions.

The platform of cooperation aimed at creating a new standard in service, was not only an entirely simple sum paid by the organization of the potentials and resources, but through interactions led to the development of new services and changes to the entire support system in Praga-North. During the project, the consortium benefited from existing resources available in the district of PragaNorth and the capital city of Warsaw. The basic method of cooperation represented interdisciplinary teams (integrated organizations and social services, cooperating in conducting impact of intervention and assistance), operating with respect for the principles of partnership and subjectivity members. In terms of integrating operations and services the project assumed: close cooperation of 
partners in planning, implementing and evaluating activities; exchange of experience and raising standards of work; cross-organizational support and undertaking new joint initiatives; integration and animate the local environment; to develop shared standards for support activities; expanding the scope of services according to the needs of the local community; integration of institutions and aid institutions in the region; the use of modern technology in the community work and increasing availability of these technologies for beneficiaries.

\section{The project 'Territorial quality standards in social services of the public benefit' and standardization of services}

Another project, which can be classified into the category of integrated social services was a project „Territorial quality standards in social services of the public benefit", which was implemented by the city of Gdynia in cooperation with several organizations gathered in the European Network for the Social Economy REVES in the period from December 2008 to October 2010. In the project a team from Gdynia animated by the Municipal Social Welfare Centre has worked primarily on the preparation of a model of determining the local criteria of the quality of social services.

An important element of the project was to determine, in the participatory formula, the demand for care services provided for the elderly, chronically ill and disabled in their place of residence. Various stakeholders were included to the public consultations: service users, their families, caregivers, volunteers, social workers, coordinators' careers, representatives of suppliers and authorities, including the authorities of the city. The final product was a 'Charter of the quality of caring' (MOPS Gdynia, 2010), used, among others, in operation since 2005 Senior Activity Centre (CAS), whose task is to coordinate activities for seniors, undertaken earlier by various social institutions and the implementation of a comprehensive activation of the elderly (Mitek, 2012). Similar initiatives have been undertaken in other cities included in the Tri-City (Gdynia, Sopot and Gdańsk), ie. 'Local Welfare Services Standard Sopot 2010','Standard of care services'- Gdańsk.

\section{Conclusion}

Regardless of the fact that our research is limited, it confirms the importance of an integrated approach in developing new effective social services.

In Poland, many public subjects are encouraging the application of integrated approaches that involve public organizations, social entrepreneurs, 
and research institutions. There is an increasing number of stakeholders who are persuaded that social innovation can be the key factor for creating and experimenting new models of governance.

The cases we presented in this paper show the importance of three main factors:

- Exchanging of ideas and values between public, private, and nonprofit sectors;

- $\quad$ Shifting roles and relationships between business, the government and nonprofits;

- $\quad$ Blending of market-based principles and mechanisms with public and philanthropic support.

Finally, our research has shown that changes in contemporary society can become opportunities for developing new social services: innovation is the driver of economic value, but social change is the driver of social innovation.

\section{References}

Bawa, A., \& Munck, R. (2012). Foreword: Globalizing civic engagement'. Higher education and civic engagement: Comparative perspectives. Palgrave MacMillan, New York, pp. 40.

Centrum Paca, http://centrumpaca.pl.

Grewiński, M. \& Karwacki, A. (2010). Pluralizm i międzysektorowa wspótpraca $w$ realizacji ustug społecznych. Mazowieckie Centrum Polityki Społecznej. Warszawa.

Gminny Ośrodek Pomocy Społecznej, Stupno, http://gops.slupno.eu.

Grewiński, M. \& Lizut, J. (2012). Pomoc społeczna jako realizator efektywnych ustug socjalnych, Regionalny Ośrodek Polityki Społecznej. Torun.

Grewiński, M. Rymsza, M. (eds.). (2011). Polityka aktywizacji w Polsce. Usługi reintegracji w sektorze gospodarki spolecznej. Warszawa.

Grewiński, M. (2014). Social Service Mix State - jako przyszłościowy model polityki społecznej w Polsce? Praca Socjalna 2/2014; 28-39

Grosse, T. G. (2008). Europa dla obywateli. Wokół jakości i dostępności usług użyteczności publicznej. Dialog, 4 (21), 9-18.

Howaldt, J., \& Schwarz, M. (2010). Social Innovation: Concepts, research fields and international trends. K. Henning, \& F. Hees (Eds.). IMA/ZLW.

Kościołek, A. (2012). Raport $z$ analizy badań ankietowych realizowanych $w$ ramach projektu „Kalkulator Kosztów Zaniechania - wprowadzenie innych rozwiazań na Mazowszu w zakresie polityki społecznej $w$ obszarze analizy kosztów braku podejmowania działań aktywizujaco wspierajacych" Downloaded from http://kkz.mcps-efs.pl.

Lettice, F., \& Parekh, M. (2010). The social innovation process: themes, challenges and implications for practice. International Journal of Technology Management, 51(1), 139-158.

Mejsner B. Lokalne inicjatywy na rzecz ustalania kryteriów jakości $i$ standaryzacji ustug opiekuńczych świadczonych $w$ miejscu zamieszkania - przykłady dobrych praktyk. Downloaded from http://www.wrzos.org.pl/projekt1.18/download/ Ekspertyza\%20ZE\% 20OS.pdf; 
Proceedings of the International Scientific Conference. Volume IV, May $27^{\text {th }}-28^{\text {th }}$, 2016. 300-310

Miejski Ośrodek Pomocy Społecznej w Gdyni, Retrieved from http://www.mopsgdynia.pl/ www/pliki/mops_w_liczbach/pomoc_spoleczna_w_gdyni_2010.pdf.

Ministerstwo Pracy i Polityki Społecznej, Retrieved from

Mitek, A. Analiza zróżnicowania poziomu finansowania świadczeń opiekuńczych $w$ ramach ubezpieczenia zdrowotnego $w$ Polsce. Downloaded from http://jmf.wzr.pl/pim/ 2013_2_5_14.pdf,

Lara Montero, A. van Duijn, S. Zonneveld, N. Minkman, M., \& Nies, H. (2016). Integrated Social Services in Europe. European Social Network. Brighton.

Miejski Ośrodek Pomocy Społecznej, Retrieved from http://mopsgdynia.pl.

Mulgan, G. (2013). Social innovation. EGEA spa.

Munday, B. (2007). Integrated social services in Europe. Downloaded from www.prissmeu.com/pdf/Publication_Integrated.pdf.

Palley, T. (2012). From financial crisis to stagnation. Cambridge: Cambridge University Press, 3(141), 53.

Program Rodzina, Retrieved from http://warszawa.pl/files/program_rodzina.pdf.

Polish Central Statistical Office, Retrieved from www.stat.gov.pl;

Radlińska, A. (2008). Perspektywy rozwoju podmiotów ekonomii społecznej $w$ branży ustugopiekuńczych. Downloaded from http://www.ekonomiaspoleczna.pl/files/ ekonomiaspoleczna. pl /public /Biblioteka/2008.13.pdf.

Urzad Miasta Warszawa, Retrieved from http:// um.warszawa.pl/node/14890. 